\title{
Cost-effectiveness analysis regarding postoperative administration of vitamin-D and calcium after thyroidectomy to prevent hypocalcaemia
}

Análisis de costo-efectividad de la administración postoperatoria de Vitamina $\mathbf{D}$ y calcio después de tiroidectomía para la prevención de la hipo calcemia

Álvaro Sanabria, Luis C. Domínguez, Valentín Vega,

Camilo Osorio y Daniel Duarte

Department of Surgery. School of Medicine. Universidad de La Sabana. Chia, Colombia. alvarosanabria@gmail.com,lucardo61@gmail.com,neilvalentin@yahoo.com, camilo.osorio@unisabana.edu.co, danielduarteca@gmail.com

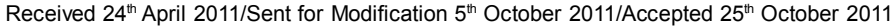

\section{ABSTRACT}

Objective Hypocalcaemia is a frequently arising complication following total thyroidectomy. Routine postoperative prophylactic administration of vitamin $\mathrm{D}$ or metabolites and calcium reduce the incidence of symptomatic hypocalcaemia; this article reports evaluating its cost-effectiveness in Colombia.

Methods Meta-analysis was used for comparing the administration of vitamin $\mathrm{D}$ or metabolites to oral calcium or no treatment at all in patients following total thyroidectomy and a cost-effectiveness analysis was designed based on a decision-tree model with local costs.

Results The OR value for the comparison between calcitriol and calcium compared to no treatment and to exclusive calcium treatment groups was $0.32(0.13-0.7995 \% \mathrm{Cl})$ and $0.31(0.14-0.7095 \% \mathrm{Cl})$, respectively. The most cost-effective strategy was vitamin $\mathrm{D}$ or metabolites and calcium administration, having a US \$0.05 incremental costeffectiveness ratio.

Conclusion Prophylactic treatment of hypocalcaemia with vitamin D or metabolites + calcium or calcium alone is a cost-effective strategy.

Key Words: Thyroid neoplasm, thyroidectomy, hypocalcaemia, cost-benefit (source: $\mathrm{MeSH}, \mathrm{NLM})$.

RESUMEN

Objetivos La hipo calcemia es la complicación más frecuente después de tiroidectomía. La administración profiláctica de vitamina D o metabolitos y calcio reduce 
la incidencia de hipocalcémia sintomática. Se evalúa su costo-efectividad en Colombia.

Materiales y métodos Utilizamos la información de un meta-análisis que comparó la administración de vitamina $\mathrm{D}$ o metabolitos contra calcio no tratamiento en pacientes llevados a tiroidectomía total y diseñamos un análisis de costo-efectividad basados en un modelos de decisiones con costos locales.

Resultados El valor del OR para la comparación entre calcitriol y calcio comparado con no tratamiento o calcio exclusivo fue de 0.32 (95 \% IC, 0.13- 0.79 ) y 0.31 (95 \% IC, $0.14-0.70)$, respectivamente. La estrategia más costo-efectiva fue la administración de vitamina $\mathrm{D}$ o metabolitos y calcio, con una relación de costo-efectividad incremental de US $\$ 0.05$.

Conclusiones El tratamiento profiláctico de la hipo calcemia con vitamina $D$ o metabolitos y calcio o calcio exclusivo después de tiroidectomía total es una estrategia costo-efectiva.

Palabras Clave: Neoplasias de tiroides, tiroidectomía, hipo calcemia, costo-beneficio (fuente: DeCS, BIREME).

7 hyroidectomy is the most common endocrine procedure performed by surgeons. Hypocalcaemia is a frequently occurring complication following total thyroidectomy and leads to prolonged hospital stay. (1-3) The rate of symptomatic postoperative hypocalcaemia ranges from $5 \%$ to $50 \%$ (4), but only $1-3 \%$ of cases are permanent and require a calcium and vitamin D supplement. Hypocalcaemia treatment depends on its severity; oral vitamin D or metabolites and calcium supplements are enough to relieve symptoms in mild cases and return serum calcium values to normal levels. Emergency admission to hospital is necessary in cases of severe hypocalcaemia, involving periodic serum calcium measurement, administration of intravenous calcium gluconate and high supplementary doses of oral vitamin D or metabolites and calcium.

It has been demonstrated that routine oral vitamin D or metabolites and calcium prophylactic administration during the postoperative period reduces symptomatic hypocalcaemia rate (5). However, the economic impact of this intervention must be assessed. Vitamin D or metabolites and calcium administration increase treatment costs because they must be used in all patients for at least one or two weeks after thyroidectomy. Such intervention's cost-effectiveness has not been assessed previously, so this therapy cannot be recommended for universal use due to health system differences.

This study was aimed at evaluating this treatment regime's costeffectiveness in a developing country's health system. 


\section{MATERIALS AND METHODS}

Data from a previous systematic review which assessed vitamin D or metabolites and calcium administration's effectiveness in patients who had undergone total thyroidectomy was used here (5).

The cost-effectiveness economic analysis was based on a deterministic and probabilistic decision-making model, selected on the premise that different therapeutic strategies have different costs and different outcomes. The reference case in the current analysis was a patient who underwent total thyroidectomy, considering thyroidectomy as a therapy for goitre and welldifferentiated thyroid carcinoma without lateral neck metastases.

Decision alternatives. Pursuant to what has been accepted in the literature, two mutually-exclusive decision alternatives were chosen as measures for preventing postoperative hypocalcaemia: postoperative supplementation with oral vitamin D or metabolites and calcium, exclusive oral calcium supplementation, both compared to no supplementation. These decision alternatives were used for assessing the following criteria: better effectiveness (using data from a previous systematic review), study design (only randomised controlled trials were included in the systematic review) and intervention and outcome costs (data was directly obtained from a first-level (highly specialised) institution and from the of the Social Security Institute of Colombia price manual).

Figure 1. Standard decision tree

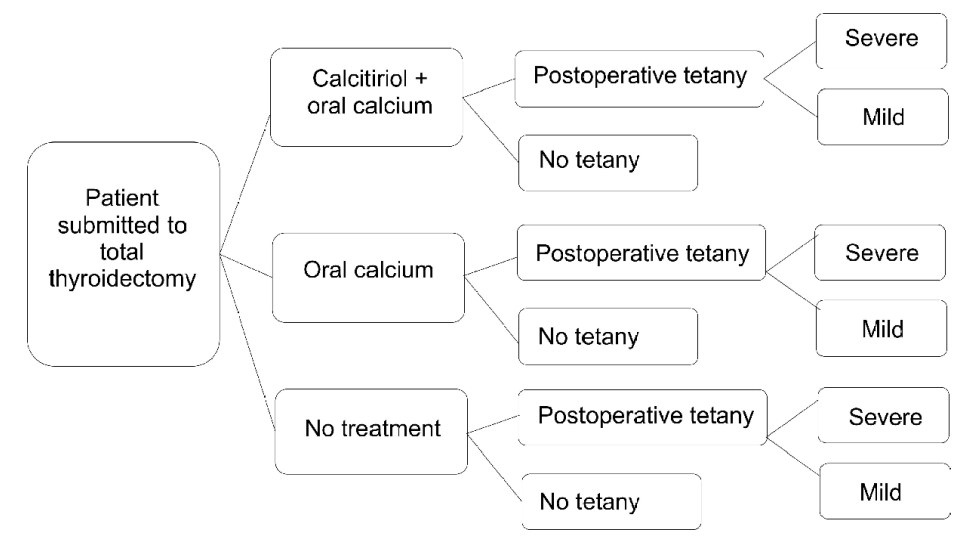


Sequences and outcome pathways. The primary outcome was the presence or absence of symptomatic postoperative hypocalcaemia, regardless of diagnostic test findings, and effectiveness was defined as the percentage of patients without symptomatic postoperative hypocalcaemia. The tree was built using TreeAge Inc DATA 4.0 software (Figure 1).

The likelihood of presenting postoperative hypocalcaemia, the probability of having a severe crisis in the patients presenting hypocalcaemia and final treatment cost were calculated for each pathway.

Analytical perspective. Health management organisations' (HMO) analytical perspective was adopted; it was chosen because such organisations ultimately pay for a particular therapeutic approach and therefore HMOs need welldocumented suggestions concerning the implementation of protocols that may be included as part of an integrated healthcare approach.

Costs. The data were obtained from a cohort of 13 patients who had presented postoperative hypocalcaemia after total thyroidectomy in a first-level institution. Such data was complemented with data obtained from the literature. HMOs are mostly concerned with direct and indirect medical costs determining the amount to be paid. The costs for the model were obtained from the Colombian Social Security Institute's billing manual for integrated care (adjusted to 2008 prices) and the Colombian Manual of Pharmaceutical Products. The diagnostic and therapeutic procedures were selected in accordance with the Social Security Institute's procedures manual. Prices were converted to US dollars using the December 2008 conversion rate ( 1 dollar=2,204 Colombian pesos). The disease was divided into two phases for estimating average costs. The acute phase included emergency department evaluation, serum calcium measurement, acute treatment with calcium gluconate and length of stay which extended until symptoms were controlled. The chronic phase included the value of administering each strategy (vitamin D or metabolites + calcium, calcium), the value of treating the hypocalcaemia episode (divided into an intensive period involving higher doses for severe hypocalcaemia (carpopedal spasm) and a maintenance period with lower doses for mild hypocalcaemia (perioral tingling) and diagnostic tests and medical evaluation used during follow-up. 
Time period. Postoperative hypocalcaemia is a condition that can be considered a short-course acute event. As the supplement was designed to alleviate the appearance of symptoms during the postoperative period, one month was considered to be sufficient time for identifying risks and benefits. Moreover, no discount adjustments were required.

Sensitivity analysis. The critical issues requiring one-way sensitivity analysis were changes in the probability of postoperative hypocalcaemia and strategy costs. A probabilistic sensitivity analysis was also designed including random distributions for probabilities of hypocalcaemia (beta), length of stay and costs (lognormal). A Monte Carlo simulation was made (10,000 trials were run). A mean and incremental cost-effectiveness plane and acceptability curve were designed.

\section{RESULTS}

The systematic review included 706 patients: 346 in the vitamin D or metabolites group, 288 in the oral calcium group and 72 in the control group. The hypocalcaemia symptom rate was 13/346 (4\%, 1-23\% range) patients in the vitamin D or metabolites group, 28/288 (19\%, 7-35\% range) in the oral calcium group and $22 / 72(31 \%, 24-41 \%$ range $)$ in the control group. The OR value for the comparison between calcitriol and calcium as compared to no treatment was $0.32(0.13-0.7995 \% \mathrm{CI})$ and $0.31(0.14-0.7095 \% \mathrm{CI})$ for the comparison between the vitamin D or metabolites and exclusive calcium treatment groups.

Probability, cost and resource use values for each strategy are shown in Tables 1, 2 and 3, respectively. Table 4 gives the deterministic model's strategy analysis results. The most cost-effective strategy was administering vitamin $\mathrm{D}$ or metabolites and calcium, having a US\$0.56 mean cost-effectiveness ratio, followed by calcium exclusively, having US $\$ 0.65$ mean costeffectiveness ratio. The no treatment branch was always dominated by the other strategies. Increased cost-effectiveness ratio for oral calcium compared to no treatment was negative and that for vitamin $\mathrm{D}$ or metabolites and calcium branch was almost 0 . The incremental cost-effectiveness ratio for vitamin $\mathrm{D}$ or metabolites and calcium compared to exclusive calcium was US\$0.32, meaning that US $\$ 0.32$ had to be provided over the cost paid for the exclusive calcium strategy to avoid a hypocalcaemia episode. 
Table 1. Probability of presenting postoperative hypocalcaemia and having a severe crisis in patients who presented hypocalcaemia and the cost of resources included in the decision tree

\begin{tabular}{|c|c|c|c|}
\hline Description & Branch & $\begin{array}{l}\text { Variable } \\
\text { name }\end{array}$ & $\begin{array}{l}\text { Probability } \\
\text { value }\end{array}$ \\
\hline Probability of having & $\begin{array}{l}\text { Vitamin D + oral calcium } \\
\text { branch }\end{array}$ & p_vitD & 0.04 \\
\hline $\begin{array}{l}\text { symptomatic } \\
\text { hypocalcaemia }\end{array}$ & $\begin{array}{l}\text { Oral calcium branch } \\
\text { No treatment branch }\end{array}$ & $\begin{array}{l}\text { p_calc } \\
\text { p_notret }\end{array}$ & $\begin{array}{l}0.19 \\
0.31\end{array}$ \\
\hline $\begin{array}{l}\text { Probability of having } \\
\text { severe symptomatic } \\
\text { hypocalcaemia }\end{array}$ & $\begin{array}{l}\text { Vitamin D + oral calcium } \\
\text { branch } \\
\text { Oral calcium branch } \\
\text { No treatment branch } \\
\end{array}$ & $\begin{array}{l}\text { p_sevvitD } \\
\text { p_sevcalc } \\
\text { p_sevno }\end{array}$ & $\begin{array}{c}0.25 \\
0.5 \\
0.68 \\
\end{array}$ \\
\hline
\end{tabular}

Table 2. Cost of resources used in the decision tree for each strategy

\begin{tabular}{lc}
\hline Item & Value (US dollars) \\
\hline Medication & \\
Calcitriol (Cap, $0.5 \mathrm{mcg})$ & 0.92 \\
Calcium carbonate (Tab, $600 \mathrm{mg})$ & 0.24 \\
Calcium gluconate $(\mathrm{Sol} 10 \%, 10 \mathrm{ml})$ & 0.91 \\
Medical services & \\
Emergency evaluation & 7.62 \\
Serum calcium measurement & 3.86 \\
Hospitalisation per day & 33.12 \\
\hline
\end{tabular}

The most relevant variables for assessing sensitivity were vitamin $\mathrm{D}$ or metabolite cost, hospitalisation days and the probability of having hypocalcaemia. A one-way sensitivity analysis showed that only a cost below US $\$ 0.58$ made the vitamin D or metabolites and calcium strategy dominant. For hospitalisation, only stays longer than 4.98 days in the calcium branch modified the dominance of the exclusive calcium strategy. Regarding the probability of having hypocalcaemia, the dominance of the exclusive calcium strategy was never surpassed in typical clinical circumstances. The costeffectiveness plane is shown in Figure 2. The most cost-effective alternative was vitamin $\mathrm{D}$ or metabolites and calcium. Figure $3 \mathrm{a}$ and $3 \mathrm{~b}$ show the incremental cost-effectiveness plane for comparing vitamin $\mathrm{D}$ or metabolites and calcium to no treatment and vitamin D or metabolites and calcium to calcium. $43.4 \%$ and $16.9 \%$ of the probabilistic trials were located in quadrant IV for the vitamin D or metabolites and calcium compared to no treatment and vitamin D or metabolites and calcium compared to calcium comparisons, respectively. The other trials were located in quadrant I. The acceptability curve showed that the vitamin D or metabolites and calcium strategy was $100 \%$ acceptable with US \$2 willingness to pay. 
Table 3. Decision tree regarding the pattern of resources used for each strategy

\begin{tabular}{|c|c|c|c|}
\hline Resource & Quantity & $\begin{array}{l}\text { Number } \\
\text { of days }\end{array}$ & $\begin{array}{l}\text { Total value } \\
\text { (US dollars) }\end{array}$ \\
\hline \multirow{2}{*}{\multicolumn{4}{|c|}{ Vitamin D or metabolites + oral calcium strategy }} \\
\hline No tetany arm & & & \\
\hline Calcium carbonate & 3600 mg/day & 15 & 21.54 \\
\hline Calcitriol & $0.5 \mathrm{mcg} /$ day & 15 & 27.46 \\
\hline Total & & & 49.00 \\
\hline \multicolumn{4}{|l|}{ Mild tetany arm } \\
\hline Emergency evaluation & 1 & & 7.62 \\
\hline Serum calcium measurement & 1 & 2 & 7.71 \\
\hline Calcium carbonate & 3600 mg/day & 2 & 2.87 \\
\hline Calcitriol & $0.5 \mathrm{mcg} / \mathrm{day}$ & 2 & 3.66 \\
\hline Calcium carbonate & $4800 \mathrm{mg} /$ day & 13 & 24.89 \\
\hline Calcitriol & $1 \mathrm{mcg} / \mathrm{day}$ & 13 & 47.59 \\
\hline Total & & & 94.35 \\
\hline \multicolumn{4}{|l|}{ Severe tetany arm } \\
\hline Emergency evaluation & 1 & & 7.62 \\
\hline Serum calcium measurement & 2 & 2 & 15.43 \\
\hline Calcium gluconate & 2 & 2 & 3.64 \\
\hline Calcium carbonate & 3600 mg/day & 2 & 2.87 \\
\hline Calcitriol & $0.5 \mathrm{mcg} / \mathrm{day}$ & 2 & 3.66 \\
\hline Calcium carbonate & 4800 mg/day & 13 & 24.89 \\
\hline Calcitriol & 1 mcg/day & 13 & 47.59 \\
\hline Hospitalization day & 1 & 2 & 66.24 \\
\hline Total & & & 171.95 \\
\hline \multicolumn{4}{|l|}{$\begin{array}{l}\text { Oral calcium strategy } \\
\text { No tetany arm }\end{array}$} \\
\hline Calcium carbonate & 3600 mg/day & 15 & 21.54 \\
\hline Total & & & 21.54 \\
\hline \multicolumn{4}{|l|}{ Mild tetany arm } \\
\hline Emergency evaluation & 1 & & 7.62 \\
\hline Serum calcium measurement & 1 & 2 & 7.71 \\
\hline Calcium carbonate & $3600 \mathrm{mg} / \mathrm{day}$ & 2 & 2.87 \\
\hline Calcium carbonate & 4800 mg/day & 13 & 24.89 \\
\hline Calcitriol & $0.5 \mathrm{mcg} / \mathrm{day}$ & 13 & 23.80 \\
\hline Total & & & 66.89 \\
\hline \multicolumn{4}{|l|}{ Severe tetany arm } \\
\hline Emergency evaluation & 1 & & 7.62 \\
\hline Serum calcium measurement & 2 & 3 & 23.14 \\
\hline Calcium gluconate & 2 & 3 & 5.46 \\
\hline Calcium carbonate & 3600 mg/day & 2 & 2.87 \\
\hline Calcium carbonate & 4800 mg/day & 13 & 24.89 \\
\hline Calcitriol & 1 mcg/day & 13 & 47.59 \\
\hline Hospitalization day & 1 & 3 & 99.36 \\
\hline Total & & & 210.94 \\
\hline \multicolumn{4}{|l|}{ No supplement arm } \\
\hline \multicolumn{4}{|l|}{ No tetany arm } \\
\hline Total & & & 0 \\
\hline \multicolumn{4}{|l|}{ Mild tetany arm } \\
\hline Emergency evaluation & 1 & & 7.62 \\
\hline Serum calcium measurement & 1 & 2 & 7.71 \\
\hline Calcium carbonate & 3600 mg/day & 13 & 18.67 \\
\hline Calcitriol & $0.5 \mathrm{mcg} / \mathrm{day}$ & 13 & 23.80 \\
\hline Total & & & 57.80 \\
\hline \multicolumn{4}{|l|}{ Severe tetany arm } \\
\hline Emergency evaluation & 1 & & 7.62 \\
\hline Serum calcium measurement & 2 & 3 & 23.14 \\
\hline Calcium gluconate & 2 & 3 & 5.46 \\
\hline Calcium carbonate & 4800 mg/day & 13 & 24.89 \\
\hline Calcitriol & $1 \mathrm{mcg} / \mathrm{day}$ & 13 & 47.59 \\
\hline Hospitalization day & 1 & 3 & 99.36 \\
\hline Total & & & 208.07 \\
\hline
\end{tabular}


Table 4. Results of cost-effectiveness analysis and incremental costeffectiveness ratio as compared to no treatment and oral calcium strategies

\begin{tabular}{|c|c|c|c|c|c|c|}
\hline Strategy & Cost & $\begin{array}{l}\text { Incremental } \\
\text { cost }\end{array}$ & Effectiveness & $\begin{array}{l}\text { Incremental } \\
\text { effectiveness }\end{array}$ & $\begin{array}{l}\text { Cost } \\
\text { effectiveness } \\
\text { ratio }\end{array}$ & $\begin{array}{l}\text { Incremental } \\
\text { cost- } \\
\text { effectiveness } \\
\text { ratio } \\
\end{array}$ \\
\hline \multicolumn{7}{|c|}{ Deterministic model } \\
\hline \multirow{3}{*}{$\begin{array}{l}\text { No treatment } \\
\text { Oral calcium } \\
\text { Vitamin D+oral } \\
\text { calcium }\end{array}$} & 49.68 & & 53 & & 0.94 & \\
\hline & 43.94 & 7.86 & 67.4 & 24.9 & 0.65 & 0.32 \\
\hline & 51.8 & 2.12 & 92.3 & 39.3 & 0.56 & 0.05 \\
\hline \multicolumn{7}{|c|}{ Probabilistic model } \\
\hline \multirow{3}{*}{$\begin{array}{l}\text { No treatment } \\
\text { Oral calcium } \\
\text { Vitamin D+oral } \\
\text { calcium }\end{array}$} & 52.2 & & 53.0 & & 0.98 & Dominated \\
\hline & 45.1 & -7.13 & 67.4 & 14.4 & 0.67 & \\
\hline & 51.8 & -0.40 & 92.2 & 39.2 & 0.56 & 0.27 \\
\hline
\end{tabular}

Figure 2. Cost-effectiveness plane

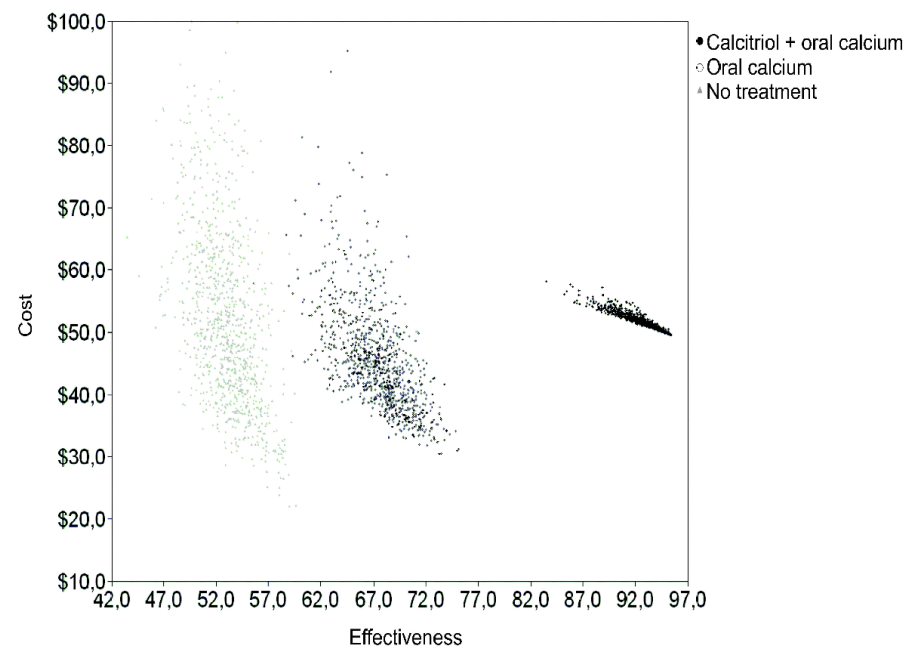


Figure 3. Incremental cost-effectiveness plane A. Vitamin D or metabolites + B. Vitamin D or metabolites +
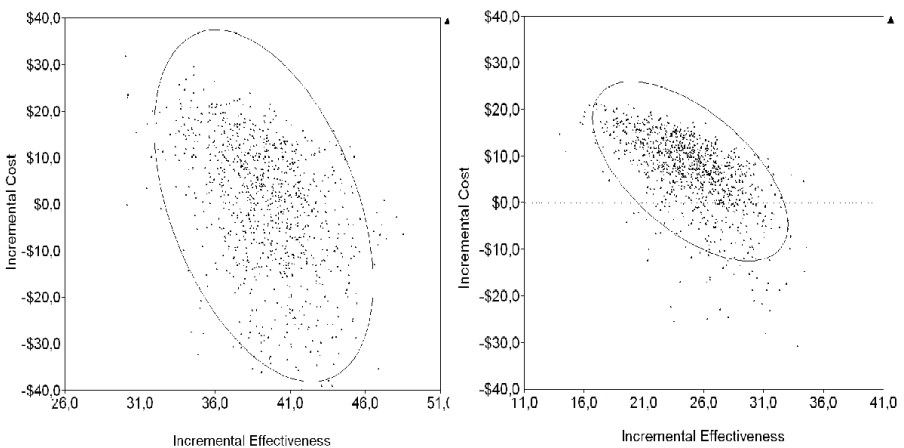

\section{DISCUSSION}

Postoperative hypocalcaemia is a common problem following thyroidectomy due to its high frequency and the decrease in quality of life for patients who suffer from severe symptoms $(1,2)$. It has been previously demonstrated that using routine prophylactic vitamin $\mathrm{D}$ or metabolites and calcium or exclusive calcium decreases hypocalcaemia rate. This approach would avoid the measurement of serum calcium before leaving the hospital and any crisis would be less severe and easy to treat (610). No cost-effectiveness studies in other countries assessing this strategy in patients who underwent thyroidectomy could be found; existing randomised controlled trials (RCT) do not offer information about this outcome. As the results of a costeffectiveness study cannot be readily extrapolated, it was thus decided to make such analysis considering cost differences in different health systems related to the local setting $(11,12)$.

Regarding costs, some surgeons have suggested that adopting routine prophylaxis with vitamin $D$ or metabolites and calcium will increase treatment cost. The current study assessed these therapeutic strategies' cost-effectiveness by means of a decision-making analysis model. The strategies based on prophylactic administration of vitamin D or metabolites and calcium or exclusive calcium were more costeffective than the no treatment branch. The most cost-effective treatment was the routine use of exclusive calcium, and the vitamin D or metabolites and calcium branch showed a US \$ 0.32 increase in cost-effectiveness ratio compared to the exclusive calcium treatment group. The sensitivity analysis showed that only a decrease in the amount of vitamin D or metabolites or a significant increase in hospital stay could modify exclusive calcium branch dominance. Probabilistic analysis also confirmed this strategy's cost-effectiveness. This study did not include utility 
values representing the quality of life experienced by patients. Therefore, the costeffectiveness analysis did not consider all important intervention outcomes. Considering that patients judge symptoms of hypocalcaemia to be very unpleasant, it can be assumed that the slight increase in cost-effectiveness found means a better quality of life, providing the intervention with a good cost-utility rate. One probable advantage not included in this economic analysis of the routine prophylaxis strategy was the avoidance of routine serum calcium measurements and the possibility of offering thyroidectomy as an outpatient procedure, because the risk of hypocalcaemia decreases to very low levels leading to more reliable out-patient control. The potential adverse events arising from using vitamin $\mathrm{D}$ or metabolites and calcium could not be measured in all patients (i.e. gastric symptoms or constipation) because they had not been suitably assessed in the systematic review and could represent an increase in costs which was not considered in the analysis. However, such events are believed to be rare and their presentation probably did not affect the final results. Thus using prophylaxis for hypocalcaemia comprising vitamin D or metabolites and calcium or exclusive calcium must be recommended as a cost-effective strategy and should be introduced into clinical practice to support the wider use of out-patient thyroidectomy

\section{REFERENCES}

1. Falk SA, Birken EA, Baran DT. Temporary postthyroidectomy hypocalcemia. Arch Otolaryngol Head Neck Surg. 1988;114:168-74.

2. Rao RS, Jog VB, Baluja CA, Damle SR. Risk of hypoparathyroidism after surgery for carcinoma of the thyroid. Head Neck. 1990;12:321-5.

3. Chia SH, Weisman RA, Tieu D, Kelly C, Dillmann WH, Orloff LA. Prospective study of perioperative factors predicting hypocalcemia after thyroid and parathyroid surgery. Arch Otolaryngol Head Neck Surg. 2006;132:41-5.

4. Pisaniello D, Parmeggiani D, Piatto A, Avenia N, d'Ajello M, Monacelli M et al. Which therapy to prevent post-thyroidectomy hypocalcemia? G Chir. 2005;26:357-61.

5. Sanabria A, Dominguez LC, Vega V, Osorio C, Duarte D. Routine Postoperative Administration Of Vitamin D And Calcium After Total Thyroidectomy: A Meta-Analysis. Int J Surg. 2010; 9:46-51.

6. Bellantone R, Lombardi CP, Raffaelli M, Boscherini M, Alesina PF, De CC, et al. Is routine supplementation therapy (calcium and vitamin $\mathrm{D}$ ) useful after total thyroidectomy? Surgery. 2002;132:1109-12.

7. Moore FD, Jr. Oral calcium supplements to enhance early hospital discharge after bilateral surgical treatment of the thyroid gland or exploration of the parathyroid glands. J Am Coll Surg. 1994;178:11-6.

8. Roh JL, Park Cl. Routine oral calcium and vitamin D supplements for prevention of hypocalcemia after total thyroidectomy. Am J Surg. 2006;192:675-8.

9. Testa A, Fant V, De RA, Fiore GF, Grieco V, Castaldi P et al. Calcitriol plus hydrochlorothiazide prevents transient post-thyroidectomy hypocalcemia. Horm Metab Res. 2006;38:821-6.

10. Uruno T, Miyauchi A, Shimizu K, Tomoda C, Takamura Y, Ito $Y$ et al. A prophylactic infusion of calcium solution reduces the risk of symptomatic hypocalcemia in patients after total thyroidectomy. World J Surg. 2006;30:304-8.

11. Bryan S, Brown J. Extrapolation of cost-effectiveness information to local settings. J Health Serv Res Policy. 1998;3:108-12.

12. Drummond MF, Bloom BS, Carrin G, Hillman AL, Hutchings HC, Knill-Jones RP et al. Issues in the cross-national assessment of health technology. Int J Technol Assess Health Care. 1992;8:671-82. 